AGORA International Journal of Juridical Sciences, www.juridicaljournal.univagora.ro

ISSN 1843-570X, E-ISSN 2067-7677

No. 4 (2014), pp. 1-6

\title{
EXERCISING THE RIGHT TO VOTE IN THE EUROPEAN ECONOMIC INTEREST GROUPING \\ C. N. Bărbieru
}

\section{Carmen - Nicoleta Bărbieru}

Faculty of Law, Private Law Department

Alexandru Ioan Cuza University of Iaşi, Romania

*Correspondence: Carmen- Nicoleta Bărbieru, Alexandru Ioan Cuza University of Iaşi, 11 Carol I St., Iaşi, Romania

E-mail: barbieru_carmen@yahoo.com

\section{Abstract}

The article proposes an analysis with respect to the exercise of the right to vote in the European Economic Interest Grouping.

Both the European legislator through the Regulation No. 2137/1985, and the Romanian one, through the Law No. 161 of April 19 $9^{\text {th }}, 2003$ related to certain measures to ensure the transparency in the exercise of the public dignities, of the public functions and in business, the prevention and sanction of corruption have given an important place to the autonomy of the will of the members with regard to the functioning of the group, the first one limited itself regarding the Organization of the group to determine the minimum number of bodies of the group, namely the decision-making and the group administrator. The analysis of the exercise of the right to vote has a triple purpose: the exercise of the right to vote, the criteria for the award of the right to vote and making decisions.

Keywords: Regulation, law, Romanian, group, vote, decisions.

\section{Introduction}

The To enable the adoption of the European Economic Interest Grouping to a multitude of $y$ situations it may face to achieve its objective, the European legislator has reserved an important place to the autonomy of will of its members regarding its operation, though it provided certain mandatory rules and it authorized the Member States to draw others into their national laws. This one, related to the European Economic Interest Grouping organization, limited itself to only set a minimum number of organs of the group, leaving to its members the opportunity to also provide the existence of other organs, provided, however, that they are stipulated in the contract of association ${ }^{\text {. }}$

Like a legal person, the European Economic Interest Grouping has no organic existence and therefore no natural will. Therefore, its will is manifested itself through its bodies.

According to Article 16 of the Regulation No.2137/1985 the will of the European Economic Interest Grouping will be formed in the body of deliberation which consists of the group members acting collectively, this body being equivalent to the general meeting of a profit making company. The Group's will be accomplished by the legal acts of the administrator or the Group's administrators ${ }^{2}$.

\footnotetext{
${ }^{1}$ Members can also predict in the content of the contract of incorporation of the grouping, bodies, such as a supervisory board, a technical committee or a censor.

${ }^{2}$ Gh. Piperea, Drept comercial, C.H. Beck Publishing House, Bucharest, 2012, pp. 139 and the next ones.
} 


\section{The Exercise of the Right to Vote}

The European legislator has not referred to as to the Regulation of the collegial body of the European Economic Interest Grouping, but it has limited to indicate how the decisionmaking power can be exercised within the group, by its members, i.e. only collectively and not individually. The Romanian legislator has not included in its national law provisions regarding the way of consulting its members, leaving them to decide on issues related to the European Economic Interest Grouping.

The absence of the name of the collective body of the European Economic Interest Grouping can be justified by the purpose for which this legal structure was created, namely to mitigate, within this cooperation, the drawbacks related to the geographical distance between its members. It also may indicate the intention of the European legislator to detach the way the decisions are made within the group, from the traditional way to make decisions within a general meeting, specific to profit-making companies.

While doing so, the legislator intended to grant greater freedom to decision-making within the European Economic Interest Grouping, either its members physically meet in a general meeting, or vote from a distance by mail or other means, some national legislations provided mandatory physical reunions of the group members for making decisions, while leaving the possibility that the decisions may be taken by written consultations, however to comply with the spirit of the Regulation.

With regard to the expression used with the Regulation to denote the collegial body of the European Economic Interest Grouping, there are different opinions in the literature. Some authors use the expression „The College of Members" ${ }^{3}$ which in their view corresponds to a broader concept than the „General Assembly”4 that they use for the meeting of the members ${ }^{5}$. However, other authors use the term „General Assembly” more traditional in the French law of the profit companies ${ }^{6}$. Considering the purpose for which the group was created, to facilitate the cross-border cooperation between its members, which involves overcoming the barriers linked, and the presence of members in a particular place, we believe that the term of the College of Members reflects better the designation of the body represented by the members of the grouping acting collectively.

Indeed, if we consider the literal meaning of the Regulation provision, designating one of the compulsory bodies of the European Economic Interest Grouping ,the members acting collectively" we may consider an European Economic Interest Grouping operating without a general meeting of its members, i.e. the assumption that its members adopt collegial decisions jointly, but without meeting physically (using postal voting, for example).

Neither the Regulation nor the Romanian law does not reveal any obligation of the members to meet, or to approve the annual accounts or to consult members on a topic concerning the administrators or one proposed by the members. This possibility of extreme decentralization fits well the purpose for which the European Economic Interest Grouping was created, namely to mitigate the drawbacks related to the geographical distance between the members, the distance given by the requirement that the members be part of two different states of the European Union.

\footnotetext{
${ }^{3}$ College: „Organ of collective leadership of the ministries and other central bodies of the State administration or certain enterprises and institutions which examines and decides on issues of competence." According to $D E X 2^{\text {nd }}$ Edition, Univers Encyclopedia Publishing House, Bucharest, 1998, p. 196.

${ }^{4}$ General Assembly: „General Assembly with the participation of members in certain organizations, enterprises, etc.", according to DEX, op. cit., p. 15.

${ }^{5}$ F. Lemeunier, Le Groupement d'intérêt économique (GIE); Groupement européen d'interet économique (GEIE), 10-e Edition, Dalloz Publishing House Paris, 1999, p. 221; A. Pételaud, La construction de la EEC et le GEIE, Revue des sociétés, 1986, p. 201; J-P Ferret, Un nouvel instrument au service de la Coopération des entreprises: le Groupement européen d'intérêt économique (GEIE), Rép Defrénois, 1989, p.409.

${ }^{6}$ C.Saint-Alary-Houin, Le Groupement européen d'intérêt économique, instrument de Coopération dans les marchés the travaux, RMC, 1993, p. 887; D. Lepeltier, G. Lesguillier, GIE, GEIE. Groupement d'intérêt économique, Groupement d'intérêt européen économique, 2e édition, GLN Joly Publishing House, Paris, 1995, pp. 137 et les suivantes.
} 


\section{N. Bărbieru}

When the members of the European Economic Interest Grouping deem appropriate to meet the members in a general meeting, it can form a single body or it can be divided into two distinct structures, such as the Ordinary General Meeting and the Extraordinary General Meeting. The members' option for a single body or one divided into two distinct parts is usually determined by the bond they have with the national corporate structures, whether they themselves are such a structure, whether they are more familiar with the way it works.

A first aspect on the general meeting to be covered by the contract for the formation of the group is its competence. Group members may agree that all the decisions be taken by the general meeting or certain tasks be assigned to the general ordinary meeting and certain tasks that to the extraordinary one. In the absence of some express provisions of the Regulation and of the Romanian law on the body where the collective will of members is formed the provisions applicable to joint stock companies or limited liability companies may constitute the inspiration and this because in the national Romanian legislation there are no rules governing the general meetings of companies of persons, companies with which the European Economic Interest Group resembles as legal structure ${ }^{7}$. The Ordinary General Assembly is the meeting that decides on the current business issues stock company, while the extraordinary one is the very existence of the group.

Regarding the exercise of voting rights issues related to the frequency of meetings, the call ways, quorum, majority of the General Meeting, the decision-making, the members' representation in the general assembly etc. would be useful to form the subject of the constituent group provisions contract.

Given that the group members are from different countries of the European Union in terms of their option to exercise their voting rights can reach out to its exercise by mail. Choosing this method of exercising the right requires the regulation by the members of the applicable rules of procedure from the form of the voting paper on which it should be determined not only the vote (positive or negative expressed by each member), but also the right content of the decision on which the members were consulted and the date when it was taken, the consultation and the deadline for submitting the voting papers, the place of consignment, the measures to be taken by the administrator in case of a delayed response of a member and any other aspect that supports the legality of the decisions taken.

\section{Criteria to Award the Right to Vote}

The right to vote is one of the fundamental prerogatives attached to a membership of the European Economic Interest Grouping ${ }^{8}$.

To ensure flexibility to the legal structure represented by the European Economic Interest Grouping, the European legislator limited itself to provide only two rules, with a mandatory character, on the assign criteria of the right to vote, the provisions of the Regulation being unfilled by the Romanian legislation governing the European Economic Interest Grouping. Thus, according to Article 17 section (1) each member has one vote. However, the incorporation agreement of the European Economic Interest Grouping may assign more than one vote to certain members, provided that no member does hold a majority.

The first rule is not to deprive any member of the main prerogative attached to his membership to an European Economic Interest Grouping, while the second was set up to avoid the situation where one member would impose his will on the other members.

Excepting these two restrictions, the group members are free to determine the manner and criteria for awarding the right to vote, their choice for a particular assignment principle of the right to vote can be influenced by the legal space in which group members come from or by their legal form.

\footnotetext{
${ }^{7}$ S. D. Carpenaru, Drept comercial român, $8^{\text {th }}$ Edition, reviewed and supplemented, Universul Juridic Publishing House, Bucharest, 2008, pp. 220-222.

${ }^{8}$ C. Gheorghe, Drept comercial european, C.H. Beck Publishing House, Bucharest, 2009, p. 138; D. Lepeltier, G. Lesguillier, op.cit., p. 137.
} 
Choosing between the egalitarian system (one member=one vote) and that of an unequal assignment of votes can be influenced on one hand by the majority laid down by law or the incorporation agreement of the group for decision making. The solution one member one vote is an optimal solution when the decisions are taken by unanimity, while the second is the right solution to majority decisions. Also, the choice of the egalitarian system for the distribution of the voting right is a solution where there are marked differences between the economic power of the members and a diversity of their legal form, in order to meet the purpose for which it was created this legal structure i.e., which is the legal instrument for cooperation.

The hypothesis of the unequal distribution choice of voting rights among the members of the European Economic Interest Grouping rises the problem of criteria, which are at the basis of assignment, criteria that may be different and may concern: participation to capital, when the grouping is set up with a capital, or the participation in financing the grouping, when it is formed without a capital, the capacity of a founding member of the group etc.

Regarding the determination of the award criteria unevenly of the voting right, we consider that the members, regardless of their legal space of origin and their legal form should take into account the character of legal instrument for cross-border cooperation of the European Economic Interest Grouping and the need to ensure a structural stability by selecting certain criteria with a low degree of variability in time.

The two mandatory rules concerning the award of the right to vote must be respected throughout the European Economic Interest Group operation, so that on the acquisition by a member by giving up to the group participation of another member is required to take into account that through this operation one member should hold the majority of votes.

\section{Making Decisions by the Voting Members}

Mainly, adopting the members' decisions by voting within the European Economic Interest Grouping is governed by the unanimity rule (Article 17 from the Regulation). This rule can be an absolute one or its applicability can be derived from the lack of certain provisions from the incorporation agreement of the European Economic Interest Grouping?

The decisions for which the unanimity rule is required are those covered by the paragraph

(2) of Article 17 of the Regulation and concern:

- alter the objects of activity of a grouping;

- alter the number of votes allotted to each member;

- alter the conditions for the decision making;

- extend the duration of a grouping beyond any period set in the incorporation agreement for the formation of the grouping;

- alter the contribution of each member or of some members to the grouping's financing. Unanimity is also required as an absolute rule, in the following cases, too:

- any member of a grouping may assign his participation in the grouping, or a proportion thereof, either to another member or to a third party;

- the assignment shall not take effect without the unanimous authorization of the other members;

- the decision to admit new members shall be taken unanimously by the members of the grouping [Article 26 section (1) of the Regulations].

If the grouping memorandum does not contain provisions by which the members derogate from the unanimity rule, the unanimous decision is required in the following cases:

- the establishment by one of a grouping member of a guarantee on his participation in a grouping [Article 22 section (1) of the Regulations];

- a member of a grouping may resign in accordance with the terms laid down in the agreement for the formation of the grouping or, in the absence of such conditions, with the unanimous consent of the other members [Article 27 paragraph (1) of the Regulations];

\footnotetext{
${ }^{9}$ D. Lepeltier, G. Lesguillier, op. cit. pp. 136; GEIE: aspects pratiques: France et autres pays de la Communauté, Levallois-Perret: Editions Francis Lefebvre, Paris, 1993, pp. 167-170.
} 


\section{N. Bărbieru}

- $\mathrm{n}$ the event of the death of an individual who is a member of the grouping, no person may become a member in his/her place except as provided by the contract for the formation of the grouping or, in its absence, with the unanimous agreement of the members [Article 28 section (2) of the Regulations].

A grouping may be dissolved up by a decision of its members ordering its dissolution. Such a decision should be taken unanimously, unless otherwise laid down in the agreement for the formation of the grouping.

The decisions for the adoption of which it is necessary unanimity are expressly provided for in the Regulations; accordingly and as otherwise clear from the provisions of section (3) of the article indicated above, all other decisions about the group can be taken by majority and quorum provided for in the articles of incorporation of the grouping. Where the contract does not provide otherwise, the decisions shall be taken unanimously.

Regarding the possibility of regulating on a conventional way the quorum and majority required for the adoption of decisions which are outside the unanimity rule we consider that it is important to analyze some issues connected to the election of quorum and majority that ensures the optimal functioning of the European Economic Interest Grouping and the scope of the conventional derogation from the unanimity rule.

Taking decisions in a general meeting requires, in the absence of such provisions both at an European level and with the Romanian law, the need of determination on a conventional of the number of members required to be present for the decisions to be representative. The members' option for a high quorum is to ensure the requirement that the decision taken within the general meeting to be representative, but it may undermine the flexibility of the legal structure created in the form of the European Economic Interest Grouping. Consequently, in the process of determining a quorum, the members should consider the need to maintain a balance between the requirement that the decisions be representative and the cross-border nature of the grouping.

In respect of terms provided that the decisions adopted by the members of a grouping also meet the vote of a majority (the favorable votes that a decision must obtain to be validly adopted). If a decision-making based on a majority was preferred to that based on an unanimous agreement establishing an European Economic Interest Grouping can specify whether it is a simple or qualified majority. The choice of the type of majority with which the decisions will be made will be based on their importance. For example, decisions regarding the voluntary dissolution of the grouping, turning the grouping into another legal form or the sale of property belonging to the grouping are decisions that by the importance they have would require a qualified majority.

The option of the European Economic Interest Grouping members for a system based on majority decision-making practices can generate three types of decisions:

- decisions to be taken by unanimity;

- decisions to be taken by qualified majority;

- decisions that are subject to a simple majority.

Taking decisions also raises the issue of decision blocking that may arise during the operation of the European Economic Interest Grouping by exercising in bad faith by one of the members of the voting rights which would not enable the unanimity, when it is required, or by regulation or by the contract of association, or as a result of a parity (equal number of positive and negative votes).

For these situations the members will have to stipulate who will have the decisive right (the members who are also managing the grouping, the president, etc.).

\section{Conclusions}

The European legislator's option to regulate by the main mandatory provisions the rules applicable in the matter of the right to vote (the way in which it can be exercised within the decision-making power of its members, the criteria for the award of the right to vote, the situations where the decisions are taken by unanimity) and leave at the same time a great 
freedom for the group members to organize the contractual relations, provides a sufficient degree of uniformity and flexibility of the group. Although a regulation in detail of the exercise of the right to vote in the European Economic Interest Group would have ensured uniformity and a high level of legal certainty, this option would have interfered to flexibility so necessary for a legal instrument for the cross-border cooperation and would have required a complete harmonization of the national laws.

\section{Bibliography:}

- Gh. Piperea, Drept comercial, C.H. Beck Publishing House, Bucharest, 2012;

- C. Gheorghe, Drept comercial european, C.H. Beck Publishing House, Bucharest, 2009;

- S. D. Carpenaru, Drept comercial român, $8^{\text {th }}$ Edition, reviewed and supplemented, Universul Juridic Publishing House, Bucharest, 2008;

- F. Lemeunier, Le Groupement d'intérêt économique (GIE); Groupement européen d'interet économique (GEIE), 10-e Edition, Dalloz Publishing House Paris, 1999;

- D. Lepeltier, G. Lesguillier, GIE, GEIE. Groupement d'intérêt économique, Groupement d'intérêt européen économique, 2e édition, GLN Joly Publishing House, Paris, 1995. 